\title{
PENGARUH RASIO TEPUNG PISANG RAJA NANGKA (Musa paradica) DAN TEPUNG KACANG MERAH (Phaseolus vulgaris L.) TERHADAP SIFAT KIMIA DAN ORGANOLEPTIK SNACK BAR
}

\author{
Ovi Nur Fita Sari \\ Mazarina Devi \\ Issutarti
}

\begin{abstract}
Abstrak: Tujuan penelitian adalah untuk menganalisis sifat kimia (protein, kalsium, zat besi) dan sifat organoleptik yang terdiri dari mutu hedonik (tekstur, aroma, rasa) serta hedonik rasa snack bar dengan rasio tepung kacang merah dan tepung pisang raja nangka 70:30\%, 60:40\%, dan 50:50\%. Penelitian ini adalah jenis penelitian eksperimen menggunakan RAL, dengan perlakuan rasio tepung pisang raja nangka dan tepung kacang merah yang berbeda. Data dianalisis menggunakan uji ANOVA. Hasil analisis sifat kimia, mutu hedonik, dan hedonik rasa snack bar menunjukkan bahwa berbeda nyata pada setiap perlakuan. Snack bar rasio tepung pisang raja nangka dan tepung kacang merah 50:50\% menghasilkan kadar protein, kalsium, dan zat besi tertinggi. Mutu hedonik tekstur dengan rerata ranking tertinggi pada rasio 50:50\% menghasilkan snack bar dengan kategori paling tidak keras. Mutu hedonik aroma dan rasa dengan rerata ranking tertinggi pada snack bar rasio 70:30\% yang menghasilkan kategori paling tidak beraroma langu tidak terasa kacang merah.
\end{abstract}

Kata-kata Kunci: balita, stunting, snack bar, sifat kimia, sifat organoleptik

\begin{abstract}
The Effect of Ratio of Banana Flour (Musa paradica) and Red Bean Flour (Phaseolus vulgaris L.) on Chemical and Organoleptic Properties of Snack Bars. This research aims to analyze the chemical properties (protein, calcium, iron) and organoleptic properties, which are consisting of hedonic quality (texture, flavor, taste) and hedonic level (taste), of snack bar with ratio of red bean flour and banana flour 70:30\% 60:40\%, and 50:50\%. This research was an experimental research using RAL, with different level of banana flour and red bean flour. The data were analyzed using ANOVA test. The results of the analyses on chemical properties, hedonic quality, and hedonic taste of snack bars showed significant differences in each treatment. Snack bar with the ratio of banana flour and red bean flour 50:50\% resulted in the highest levels of protein, calcium and iron. The highest rank of the hedonic quality was obtained from the flour ratio of 50:50\% and resulting in the snack bar with the least hardness category. The hedonic quality of the aroma and taste with the highest ranking ranks was found in the snack bar with the flour ratio of 70:30\%, in which the results were the least flavorful category and in the least red bean category.
\end{abstract}

Keywords: toddlers, stunting, snack bar, chemical properties, organoleptic properties

Ovi Nur Vita Sari adalah Mahasiswa Jurusan Teknologi Industri Universitas Negeri Malang. Alamat Kampus: Jl. Semarang No. 5 Malang 65145. Email: ovinurfitasari33@gmail.com. Mazarina Devi dan Issutarti adalah Dosen Jurusan Teknologi Industri Universitas Negeri Malang. Alamat Kampus: J. Semarang No. 5 Malang 65145 
akibat pada pemenuhan ketersediaan pangan terhadap kebutuhan gizi dan kesehatan anggota keluarga diantaranya adalah kesehatan balita. Akibatnya balita akan mengalami defisiensi gizi. Menurut Handayani (2008) usia di balita merupakan "usia emas" dalam pembentukan sumberdaya manusia baik dari segi pertumbuhan fisik maupun kecerdasan, dimana hal tersebut harus didukung oleh status gizi yang baik. Berdasarkan data Kementerian Kesehatan RI (2014) yang menyatakan bahwa secara keseluruhan prevalensi anak balita stunting yaitu 9,50\%. Dalam mencapai target internasional Sustainable Development Goals (SGDs) tahun 2025 terkait mengakhiri malnutrisi dan menurunkan angka stunting pada balita diperlukan pencegahan serta penanganan yang baik. Salah satunya dengan membantu mencukupi kebutuhan gizi balita melalui pengembangan formulasi makanan tambahan fungsional yang standar gizi dan mampu meningkatkan imunitas balita dengan mempertimbangkan keunggulan sumberdaya pangan lokal (Kusharto, dkk, 2009).

Salah satu carayang dapat dilakukan yaitu melalui pengembangan makanan tambahan fungsional.Makanan tambahan yang memiliki standar gizi yang baik dan mampu meningkatkan imunitas balita dengan mempertimbangkan keunggulan sumberdaya pangan lokal seperti biscuit (Kusharto, dkk., 2009).

Menurut SNI tahun 2011, biskuit diklasifikasikan menjadi biskuit keras, crackers, cookies, dan wafer. Snack bar digolongkan dalam cookies karena berbentuk padat. Snack bar dipilih sebagai makanan tambahan untuk balita karena snack bar merupakan camilan sehat yang mengandung gizi yang baik yaitu protein, karbohirat, vitamin, dan mineral. Memiliki rasa yang manis, tekstur empuk dan tidak keras sesuai selera balita. Bahan pembuatan snack bar dapat diformulasi menggunakan bahan pangan lokal dari tepung kacang merah dan tepung pisang raja nangka.

Pisang dikenal dengan buah yang kaya akan mineral, seperti kalium, magnesium, fosfor, kalsium, dan zat besi (Cahyono, 2009). Mineral yang terkandung dalam pisang sangat dibutuhkan untuk pertumbuhan dan perkembangan anak serta dapat terserap oleh tubuh hingga 100,00\% dibandingkan dengan pangan nabati lainnya (Supriyadi, 2012). Selain itu, pisang raja nangka mudah diperoleh dengan harga yang terjangkau. Sementara itu, kacang merah mengandung karbohidrat kompleks, serat makanan (fiber), vitamin B, fosfor, mangan, besi, thiamin, dan protein yang baik untuk kebutuhan gizi yang kurang pada balita (Verawati, 2015). Kacang merah juga mengandung kalsium $260 \mathrm{mg} / 100 \mathrm{gr}$ yang lebih tinggi jika dibandingkan dengan kacang hijau $125 \mathrm{mg} / 100$ gr (Astawan, 2009).

Penelitian ini meneliti tentang sifat kimia (protein, kalsium, zat besi), mutu hedonik (tekstur, aroma, rasa) dan tingkat kesukaan terhadap rasa snack bar dengan rasio tepung kacang merah dan tepung pisang raja nangka 70:30\%, 60:40\%, dan 50:50\%.

\section{METODE}

Jenis penelitian ini adalah penelitian eksperimen. Rancangan percobaan menggunakan Rancangan Acak Lengkap (RAL). Perlakuan yang digunakan pada penelitian ini adalah snack bar rasio tepung pisang raja nangka dan tepung kacang merah yang berbeda yaitu 70:30\%, 60:40\%, dan 50:50\%.

Pengamatan dilakukan terhadap sifat kimia (kadar protein, kalsium, zat besi), mutu hedonik (tekstur, aroma, rasa) dan hedonik rasa snack bar. Metode yang digunakan yaitu, analisis protein (Metode kjeldahl), kalsium dan zat besi (Metode Spektrofotometri Serapan Atom (SSA). 
Bahan analisis meliputi Labu Kjeldahl, $\mathrm{K}_{2} \mathrm{SO}_{4}, \mathrm{CuSO}_{4}$, selenium, $\mathrm{H}_{2} \mathrm{SO}_{4}$ pekat, aquades, $\mathrm{NaOH}, \mathrm{HCl}$, dan $\mathrm{H}_{3} \mathrm{BO}_{3}, \mathrm{HNO}_{3}$, asam khlorida pekat, $\mathrm{HNO}_{3}$ pekat p.a, $\mathrm{HCl}$ pekat p.a, larutan induk besi, dan kertas saring. Bahan pembuatan snack bar adalah tepung pisang raja nangka, tepung kacang merah, tepung beras, sirup gula, margarin, garam, selai pisang, sale pisang, dan air. Formula snack bar tepung pisang raja nangka dan tepung kacang merah dapat dilihat pada Tabel.1.

Alat yang digunakan dalam proses pembuatan snack bar adalah timbangan, bowl, spatula, rolling pin, loyang, ring cutter, dan oven. Alat yang digunakan untuk analisis kimia yaitu, timbangan analitik, karet hisap, labu kjeldahl, lemari asam, set destilasi, erlenmeyer, buret, statif, klem, pipet tetes, pipet volum, pipet skala, labu takar, mortal martil, spatula, spektrofotometer serapan atom (SSA), penegas listrik, neraca analitik, tanur listrik, labu takar, erlenmeyer, cawan penguap, corong, batang pengaduk, sendok zat.

Panelis yang dilibatkan pada uji mutu hedonik yaitu panelis agak terlatih sebanyak 35 orang sedangkan uji hedonik rasa yaitu anak-anak usia 3-5 tahun sebanyak 50 orang dengan masing-masing dua kali pengulangan. Data hasil penelitian uji kimia (kadar protein, kalsium, zat besi), mutu hedonik (tekstur, aroma, rasa) dan hedonik rasa snack bar dianalisis dengan metode One-Way ANOVA menggunakan SPSS 21.0 Statistic Software dengan level signifikan a $=0,05$. Jika terdapat perbedaan yang nyata dilanjutkan dengan uji DMRT.

\section{HASIL}

Hasil rerata kadar protein snack bar tepung pisang raja nangka dan tepung kacang merah dapat dilihat pada Tabel 2.

Hasil uji ANOVA kadar protein snack bar pada $\alpha=0,05$ diperoleh nilai signifikansi sebesar 0,002. Nilai signifikansi tersebut menunjukkan bahwa terdapat perbedaan yang nyata pada ketiga rasio snack bar. Analisis dilanjutkan dengan Uji Duncan's Multiple Range Test (DMRT) untuk mengetahui perbedaan kadar protein antar rasio snack bar tepung pisang raja nangka dan tepung kacang merah.

Tabel 1. Formula Snack Bar Tepung Pisang Raja Nangka dan Tepung Kacang Merah

\begin{tabular}{lllll}
\hline No. & Bahan & Formula 1 & Formula 2 & Formula 3 \\
\cline { 3 - 5 } & & $\mathbf{7 0 : 3 0 \%}$ & $\mathbf{6 0 : 4 0 \%}$ & $\mathbf{5 0 : 5 0 \%}$ \\
\hline 1. & Tepung pisang raja nangka & 105 & 90 & 75 \\
2. & Tepung kacang merah & 45 & 60 & 75 \\
3. & Tepung beras & 12 & 12 & 12 \\
4. & Sirup gula & 60 & 60 & 60 \\
5. & Margarin & 40 & 40 & 40 \\
6. & Garam & 4 & 4 & 4 \\
7. & Selai pisang & 60 & 60 & 60 \\
8. & Sale pisang & 25 & 25 & 25 \\
9. & Air & 10 & 10 & 10 \\
\hline
\end{tabular}

Tabel 2. Rerata Kadar Protein Snack Bar Tepung Pisang Raja Nangka dan Tepung Kacang Merah

\begin{tabular}{lccc}
\hline \multirow{2}{*}{ Formula } & \multicolumn{2}{c}{ Protein (gr/100gr) } & \multirow{2}{*}{ Rerata } \\
\cline { 2 - 3 } & $\mathbf{1}$ & $\mathbf{2}$ & 17.785 \\
\hline Formula A & 17.702 & 17.867 & 18.644 \\
Formula B & 18.475 & 18.814 & 19.928 \\
Formula C & 19.868 & 19.987 & \\
\hline
\end{tabular}


Hasil uji DMRT menunjukkan bahwa kadar protein ketiga rasio snack bar tepung pisang raja nangka dan tepung kacang merah 70:30, 60:40\%, dan 50:50\% berbeda nyata antara satu sama lain. Kadar protein tertinggi terdapat pada snack bar rasio 50:50\%. Hasil rerata kadar kalsium snack bar tepung pisang raja nangka dan tepung kacang merah dapat dilihat pada Tabel 3.

Hasil uji ANOVA kadar kalsium snack bar pada $\alpha=0,05$ diperoleh nilai signifikansi sebesar 0,000 . Nilai signifikansi tersebut menunjukkan bahwa terdapat perbedaan yang nyata pada ketiga rasio snack bar. Analisis dilanjutkan dengan Uji Duncan's Multiple Range Test (DMRT) untuk mengetahui perbedaan kadar kalsium antar rasio snack bar tepung pisang raja nangka dan tepung kacang merah.

Hasil uji DMRT menunjukkan bahwa kadar kalsium ketiga rasio snack bar tepung pisang raja nangka dan tepung kacang merah 70:30, 60:40\%, dan 50:50\% berbeda nyata antara satu sama lain. Kadar kalsium tertinggi terdapat pada snack bar rasio 50:50\%.

Hasil rerata kadar zat besi snack bar tepung pisang raja nangka dan tepung ka-

Tabel 3. Rerata Kadar Kalsium Snack Bar Tepung Pisang Raja Nangka dan Tepung Kacang Merah

\begin{tabular}{lccc}
\hline \multirow{2}{*}{ Rasio } & \multicolumn{2}{c}{ Ca (mg/100g) } & \multirow{2}{*}{ Rerata } \\
\cline { 2 - 3 } & $\mathbf{1}$ & $\mathbf{2}$ & 170,368 \\
$70: 30 \%$ & 168,561 & 172,174 & 216,259 \\
$60: 40 \%$ & 214,437 & 218,082 & 253,785 \\
$50: 50 \%$ & 255,236 & 252,335 & \\
\hline
\end{tabular}

Tabel 4. Rerata Kadar Zat Besi Snack Bar Tepung Pisang Raja Nangka dan Tepung Kacang Merah

\begin{tabular}{|c|c|c|c|}
\hline \multirow{2}{*}{ Rasio } & \multicolumn{2}{|c|}{$\mathrm{Fe}(\mathrm{mg} / \mathbf{1 0 0 g})$} & \multirow{2}{*}{ Rerata } \\
\hline & 1 & 2 & \\
\hline $70: 30 \%$ & 2,402 & 2,444 & 2,423 \\
\hline 60:40\% & 3,243 & 3,331 & 3,287 \\
\hline 50:50\% & 3,902 & 3,942 & 3,922 \\
\hline
\end{tabular}

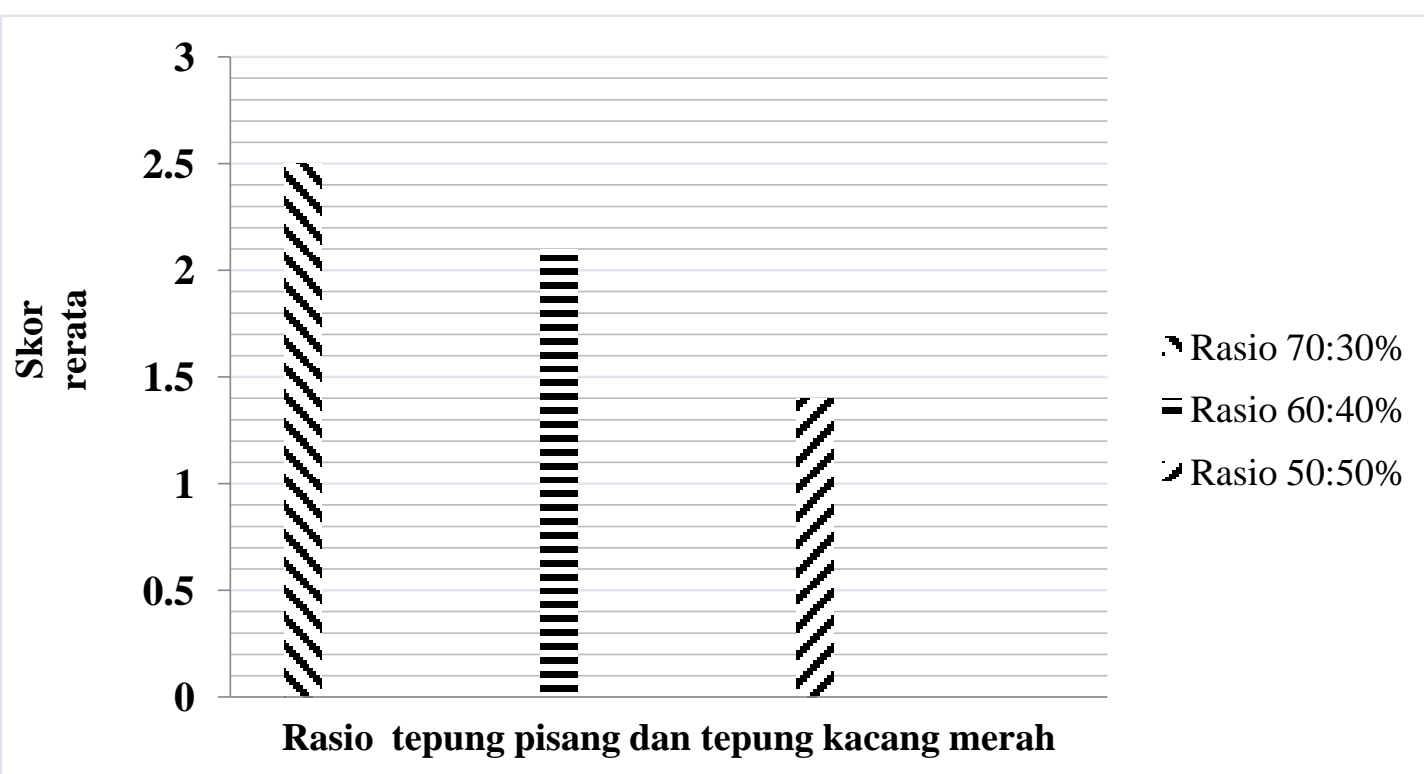

Gambar 1. Grafik Rerata Mutu Hedonik Tekstur 
cang merah dapat dilihat pada Tabel 4.

Hasil uji ANOVA kadar zat besi snack bar pada $\alpha=0,05$ diperoleh nilai signifikansi sebesar 0,000 . Nilai signifikansi tersebut menunjukkan bahwa terdapat perbedaan yang nyata pada ketiga rasio snack bar. Analisis dilanjutkan dengan Uji Duncan's Multiple Range Test (DMRT) untuk mengetahui perbedaan kadar zat besi antar rasio snack bar tepung pisang raja nangka dan tepung kacang merah.

Hasil uji DMRT menunjukkan bahwa kadar zat besi ketiga rasio snack bar tepung pisang raja nangka dan tepung kacang merah 70:30, 60:40\%, dan 50:50\% berbeda nyata antara satu sama lain. Kadar zat besi tertinggi terdapat pada snack bar rasio 50:50\%.
Hasil analisis rerata uji ranking panelis terhadap mutu hedonik tekstur snack bar tepung pisang raja nangka dan tepung kacang merah dapat dilihat pada Gambar 1.

Hasil uji ANOVA mutu hedonik tekstur atribut tingkat kekerasan snack bar pada $\alpha=0,05$ diperoleh nilai signifikansi sebesar 0,000. Nilai signifikansi tersebut menunjukkan bahwa terdapat perbedaan yang nyata pada ketiga rasio snack bar. Analisis dilanjutkan dengan Uji Duncan's Multiple Range Test (DMRT) untuk mengetahui perbedaan mutu hedonik tekstur antar rasio snack bar tepung pisang raja nangka dan tepung kacang merah.

Hasil uji DMRT menunjukkan bahwa mutu hedonik tekstur ketiga rasio

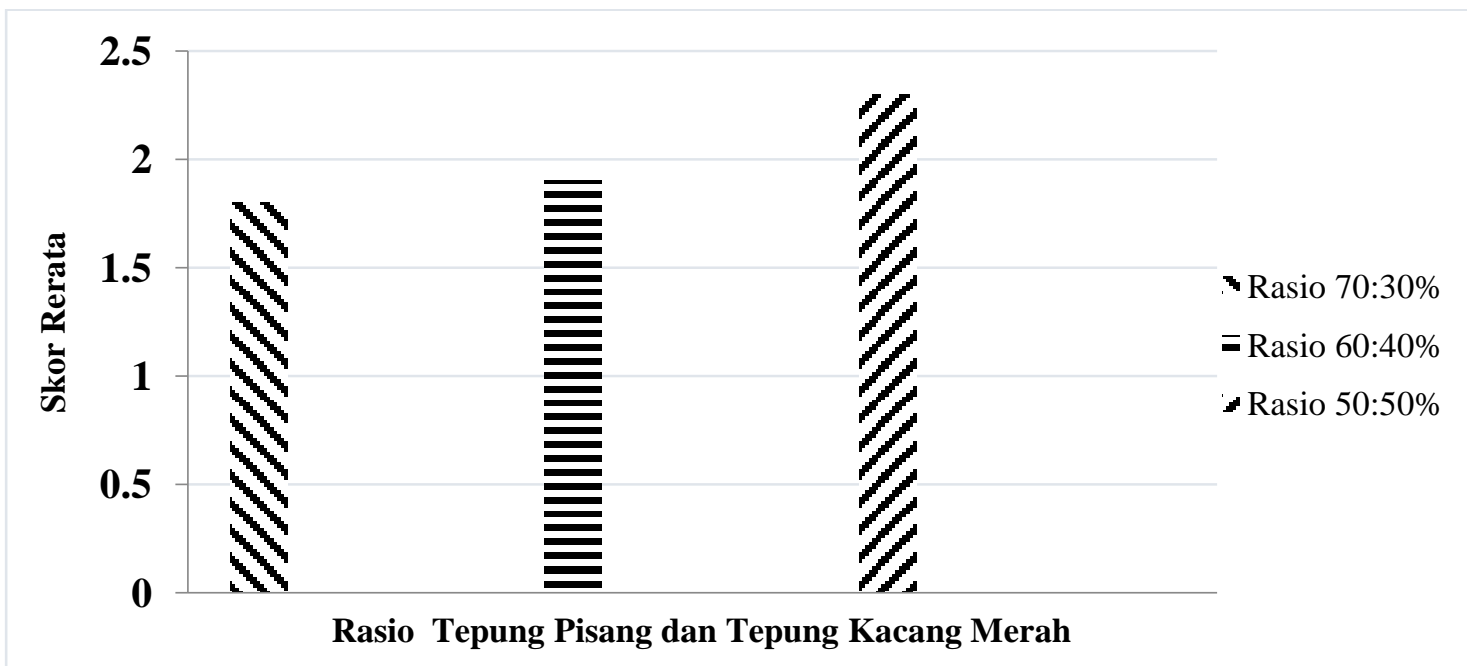

Gambar 2. Grafik Rerata Mutu Hedonik Aroma

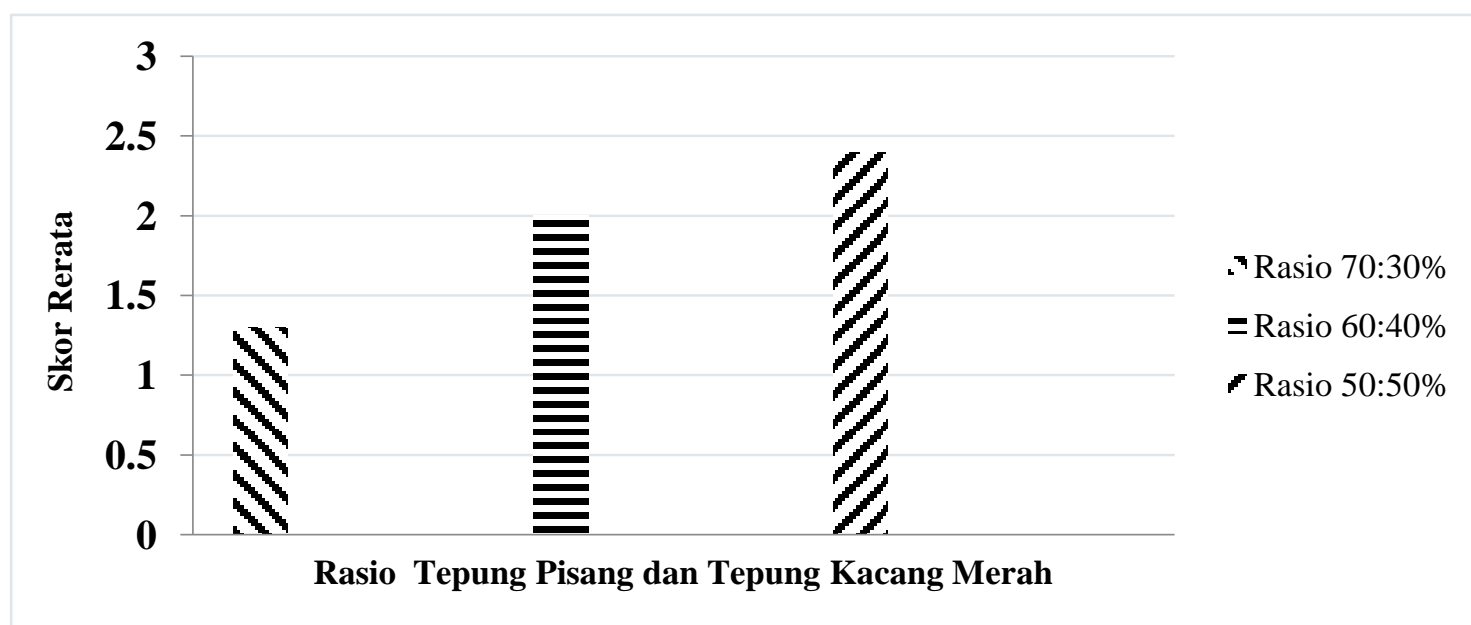

Gambar 3. Grafik Rerata Mutu Hedonik Rasa 
snack bar tepung pisang raja nangka dan tepung kacang merah 70:30, 60:40\%, dan 50:50\% berbeda nyata antara satu sama lain. Ranking tertinggi mutu hedonik tekstur atribut tingkat kekerasan terdapat pada snack bar rasio 50:50\% yang menunjukkan paling tidak keras, sedangkan ranking terendah terdapat pada snack bar rasio $70: 30 \%$ yang menunjukkan paling keras.

Hasil analisis rerata uji ranking panelis terhadap mutu hedonik aroma snack bar tepung pisang raja nangka dan tepung kacang merah dapat dilihat pada Gambar 2.

Hasil uji ANOVA mutu hedonik aroma atribut intensitas aroma langu snack bar pada $\alpha=0,05$ diperoleh nilai signifikansi sebesar 0,002. Nilai signifikansi tersebut menunjukkan bahwa terdapat perbedaan yang nyata pada ketiga rasio snack bar. Analisis dilanjutkan dengan Uji Duncan's Multiple Range Test (DMRT) untuk mengetahui perbedaan mutu hedonik aroma antar rasio snack bar tepung pisang raja nangka dan tepung kacang merah.

Hasil uji DMRT menunjukkan bahwa mutu hedonik aroma snack bar rasio 70:30\% tidak berbeda nyata dengan rasio $60: 40 \%$, sedangkan rasio $70: 30 \%$ dan $60: 40 \%$ berbeda nyata dengan rasio 50:50\%. Ranking tertinggi mutu hedonik aroma atribut intensitas aroma langu terdapat pada snack bar rasio 70:30\% yang menunjukkan paling tidak langu, sedangkan ranking terendah terdapat pada snack bar rasio 50:50\% yang menunjukkan paling langu.

Hasil analisis rerata uji ranking panelis terhadap mutu hedonik rasa snack bar tepung pisang raja nangka dan tepung kacang merah dapat dilihat pada Gambar 3.

Hasil uji ANOVA mutu hedonik rasa atribut intensitas rasa kacang merah snack bar pada $\alpha=0,05$ diperoleh nilai signifikansi sebesar 0,000 . Nilai signifikansi tersebut menunjukkan bahwa terdapat perbedaan yang nyata pada ketiga rasio snack bar. Analisis dilanjutkan dengan Uji Duncan's Multiple Range Test (DMRT) untuk mengetahui perbedaan mutu hedonik rasa antar rasio snack bar tepung pisang raja nangka dan tepung kacang merah.

Hasil uji DMRT menunjukkan bahwa mutu hedonik rasa ketiga rasio snack bar tepung pisang raja nangka dan tepung kacang merah 70:30, 60:40\%, dan 50:50\% berbeda nyata antara satu sama lain. Ranking tertinggi mutu hedonik rasa atribut intensitas rasa kacang terdapat pada snack bar rasio 70:30\% yang menunjuukan paling tidak terasa kacang merah, sedangkan ranking terendah terdapat

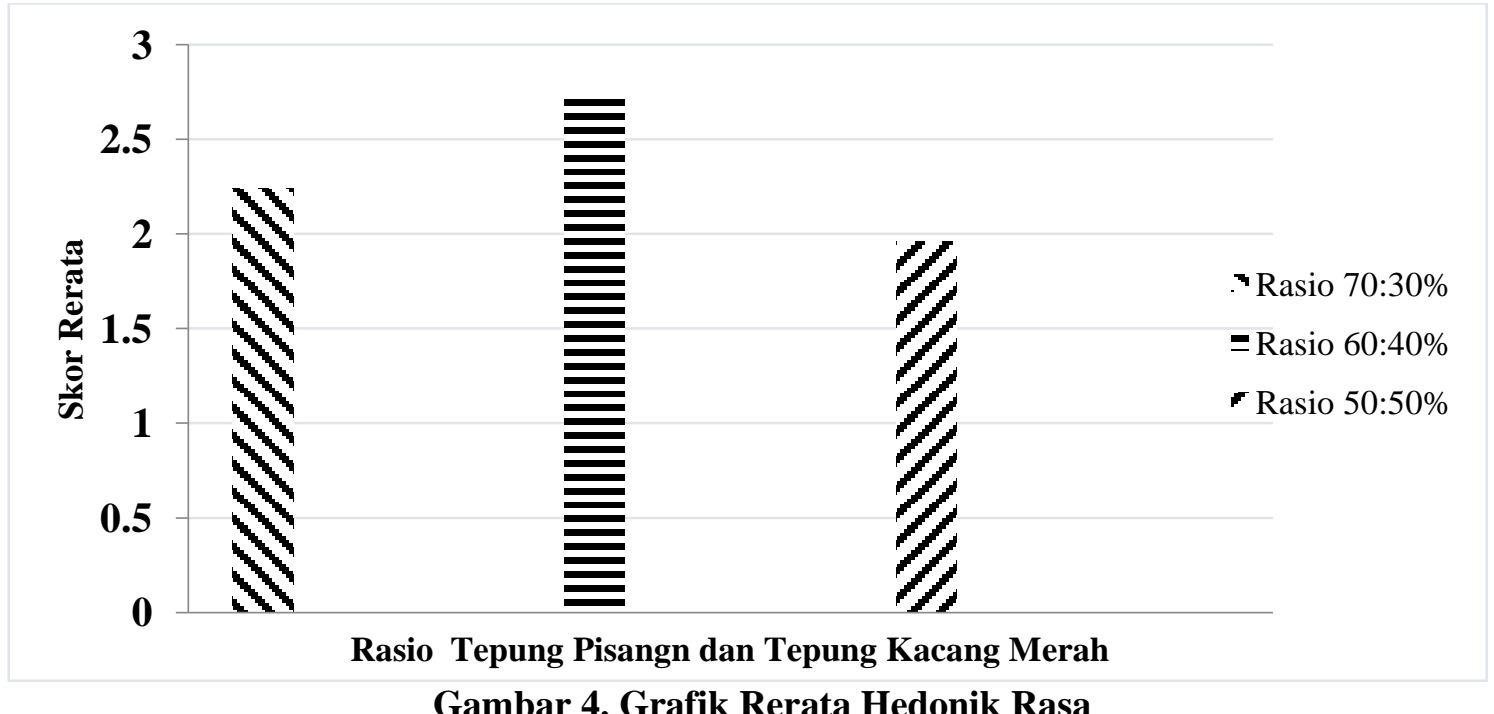

Gambar 4. Grafik Rerata Hedonik Rasa 
pada snack bar rasio 50:50\% yang menunjukkan paling terasa kacang merah.

Hasil analisis rerata uji hedonik panelis balita usia 3-5 tahun terhadap hedonik rasa snack bar tepung pisang raja nangka dan tepung kacang merah dapat dilihat pada Gambar 4.

Hasil uji ANOVA hedonik rasa snack bar pada $\alpha=0,05$ diperoleh nilai signifikansi sebesar 0,000 . Nilai signifikansi tersebut menunjukkan bahwa terdapat perbedaan yang nyata pada ketiga formula snack bar. Analisis dilanjutkan dengan Uji Duncan's Multiple Range Test (DMRT) untuk mengetahui perbedaan hedonik rasa antar rasio snack bar tepung pisang raja nangka dan tepung kacang merah.

Hasil uji DMRT menunjukkan bahwa hedonik rasa ketiga rasio snack bar tepung pisang raja nangka dan tepung kacang merah 70:30, 60:40\%, dan 50:50\% berbeda nyata antara satu sama lain. Ranking tertinggi hedonik rasa terdapat pada snack bar rasio 60:40\% dengan skor tertinggi $(2,72)$ menunjukkan suka, sedangkan ranking terendah $(1,96)$ terdapat pada snack bar rasio 50:50\% menunjukkan biasa saja.

\section{PEMBAHASAN}

Kadar protein snack bar tepung pisang raja nangka dan tepung kacang merah dalam penelitian ini meningkat seiring penambahan rasio tepung kacang merah yang ditingkatkan. Peningkatan kadar protein seiring dengan peningkatan penambahan tepung kacang merah dikarenkana protein pada kacang merah lebih tinggi dibanding protein pisang nangka Hal ini sejalan dengan hasil penelitian Fatimah, dkk (2015) yang menyatakan protein biskuit subtitusi tepung kacang merah semakin meningkat seiring penambahan tepung kacang merah yang ditingkatkan.
Berdasarkan AKG (2014) kebutuhan protein untuk anak usia 3-5 tahun sebanyak 35 gr/hari. Berat per keping snack bar tepung pisang raja nangka dan tepung kacang merah rasio (50:50\%) adalah 15 gr mengandung protein 2,9 gr. Jumlah tersebut dapat menyumbang 8,3\% kebutuhan protein pada balita dalam sehari.

Kadar kalsium snack bar pada penelitian ini semakin meningkat seiring rasio tepung kacang merah yang ditingkatkan. Hal tersebut sejalan dengan hasil penelitian (Rukmi, 2009) terkait snack ekstrusi jagung dengan substitusi kacang merah menyatakan bahwa kadar kalsium semakin meningkat seiring dengan besarnya konsentrasi kacang merah yang ditambahkan. Kacang merah termasuk dalam golongan kacang-kacangan yang memiliki kandungan kalsium yang lebih tinggi dibanding kacang hijau (Astawan, 2009).

Berdasarkan AKG (2014) kebutuhan kalsium untuk anak usia 3-5 tahun berkisar antara $1000 \mathrm{mg} / \mathrm{hari}$. Berat satu keping snack bar dengan rasio tepung pisang raja nangka dan tepung kacang merah (50:50\%) adalah 15 gr dan mengandung kalsium $38 \mathrm{mg}$. Jumlah tersebut dapat menyumbang 3,8\% kebutuhan kalsium pada balita dalam sehari.

Kadar zat besi snack bar pada penelitian ini meningkat seiring penambahan rasio tepung kacang merah yang ditingkatkan. Meningkatnya kadar zat besi karena kacang merah mengandung zat besi lebih tinggi jika dibanding pisang raja nangka (Kementrian Kesehatan RI, 2014). Berdasarkan penelitian yang telah dilakukan Setiawan \& Yustiyani (2013) terkait bubur instan menggunakan komposit tepung kacang merah dan pati ganyong menyatakan bahwa kadar zat besi bubur instan semakin meningkat seiring penambahan tepung kacang merah yang ditingkatkan. 
Berdasarkan AKG (2014) kebutuhan zat besi untuk anak usia 3-5 tahun berkisar antara $9 \mathrm{mg} /$ hari. Berat satu keping snack bar dengan rasio tepung pisang raja nangka dan tepung kacang merah (50:50\%) adalah 15 gr dan mengandung kadar zat besi 0,6 mg. Jumlah tersebut dapat menyumbang $6,6 \%$ kebutuhan zat besi ada balita dalam sehari.

Tekstur yang dihasilkan snack bar dengan semakin tinggi rasio tepung pisang raja nangka tingkat kekerasan snack bar semakin meningkat. Meningkatnya tingkat kekerasan suatu produk pangan dapat dipengaruhi oleh kandungan pati yang terdapat pada bahan dasar yang digunakan (Supriyadi, 2012). Menurut (Winarno, 2004) pati tersusun dari dua fraksi utama yaitu amilosa dan amilopektin. Semakin tinggi amilosa dan rendah amilopektin maka tingkat kekerasan tekstur produk semakin meningkat. Hal ini disebabkan kandungan amilosa yang tinggi pada tepung pisang raja nangka. Kandungan amilosa dan amilopektin yang terdapat pada tepung pisang raja nangka sebanyak 61\% dan 39\% (Rosida, 2011). Sementara itu, menurut Astawan (2009) kandungan amilosa dan amilopektin tepung kacang merah sebanyak 29\% dan $71 \%$.

Aroma yang dihasilkan snack bar dengan semakin tinggi rasio tepung kacang merah aroma yang dihasilkan semakin langu. Menurut Astawan (2009) bahwa bau langu disebabkan oleh aktivitas enzim lipoksigenase yang secara alami terdapat pada kacang-kacangan, salah satunya yang terdapat dalam kacang merah. Enzim lipoksigenase pada kacang merah sebelumnya sudah dikurangi pada saat proses pemanggangan snack bar pada suhu $160^{\circ} \mathrm{C}$ selama 40 menit. Hal ini karena proses pemanasan selama beberapa menit dapat mengurangi aroma langu serta enzim lipoksigenase sebagian akan rusak dan tidak aktif pada suhu $79,4^{\circ} \mathrm{C}$ (Desrosier, 1988).
Intensitas rasa kacang merah pada snack bar semakin kuat seiring semakin tinggi rasio tepung kacang merah. Citarasa kacang merah yang kuat disebabkan kandungan senyawa saponin pada kacang merah (Kurniasih \& Rosahdi, 2013). Senyawa tersebut dapat dikurangi melalui proses pemanasan, fermentasi, dan perendaman (Dewi \& Panunggal, 2016). Pada proses pembuatan tepung kacang merah dilakukan perendaman kacang merah selama 12 jam untuk melunakkan tekstur kacang merah. Proses perendaman tersebut juga untuk mengurangi citarasa kacang merah yang kuat pada snack bar. Selanjutnya pada proses pemanggangan snack bar pada suhu $160^{\circ} \mathrm{C}$ selama 40 menit selain bertujuan untuk proses pematangan, diduga bisa mengurangi citarasa kacang merah yang kuat pada snack bar yang dihasilkan.

Snack bar tepung pisang raja nangka dan tepung kacang merah rasio 60:40\% disukai karena menghasilkan snack bar dengan rasa kacang merah yang tidak terlalu kuat dan rasa yang tidak asam khas pisang raja nangka. Snack bar rasio 50:50\% kurang disukai karena produk yang dihasilkan memiliki rasa khas kacang merah yang lebih kuat dibandingkan rasio 60:40\%. Yuliana (2006) menyatakan bahwa cita rasa khas kacang merah berpengaruh pada tingkat kesukaan panelis terhadap biskuit subtitusi tepung kacang merah. Berdasarkan uji mutu hedonik rasa yang telah dilakukan seiring banyak rasio tepung kacang merah yang digunakan menghasilkan produk snack bar dengan intensitas rasa kacang merah yang semakin kuat.

\section{SIMPULAN DAN SARAN}

Berdasarkan penelitian yang telah dilakukan terhadap snack bar tepung pisang raja nangka dan tepung kacang me- 
rah diperoleh kesimpulan bahwa analisis sifat kimia, mutu hedonik, dan hedonik rasa snack bar menunjukkan bahwa berbeda nyata pada setiap perlakuan. Snack bar rasio tepung pisang raja nangka dan tepung kacang merah (50:50\%) menghasilkan kadar protein, kalsium, dan zat besi tertinggi. Mutu hedonik tekstur dengan rerata ranking tertingg terdapat pada rasio $(50: 50 \%)$. Mutu hedonik aroma terbaik adalah snack bar rasio 70:30\% dan mutu hedonik rasa terbaik terdapat pada snack bar rasio 70:30\% yang menghasilkan kategori paling tidak terasa kacang merah. Hedonik rasa snack bar yang disukai adalah snack bar dengan rasio 60:40\%.

Saran untuk peneliti selanjutnya adalah sebagai berikut, perlu dilakukan penelitian lanjutan agar snack bar rasio tepung pisang raja nangka dan tepung kacang merah $50: 50 \%$ yang memiliki kandungan gizi tertinggi lebih disuka oleh balita. Perbaikan produk dapat dilakukan dengan pemberian topping atau coating pada snack bar agar lebih disukai oleh balita.

\section{DAFTAR RUJUKAN}

Astawan, M. 2009. Sehat Dengan Makanan Berkhasiat. Jakarta: Buku Kompas.

Cahyono, B. 2009. Pisang. Yogyakarta: Kanisius (Anggota IKAPI).

Desrosier, N.W. 1988. Teknologi Pengawetan Pangan. UI Press. Jakarta.

Dewi, L.K. \& Panunggal, B. 2016. Analisis Kadar Saponin Dan Total Bakteri Asam Laktat Pada Yogurt Ganyong (Canna edulis) Sinbiotik Substitusi Kacang MeraH (Phaseolus vulgaris 1.). Journal of Nutrition College, 5(1): $14-19$.

Fatimah, P.S., Nasution. E., \& Aritonang, E.Y. 2015. Uji Daya Terima dan Nilai Gizi Biskuit yang Domodifi- kasi dengan Tepung Kacang Merah. Jurnal Kesehatan Masyarakat USU.

Handayani, I.S. 2008. Hubungan Antara Sosial Ekonomi Keluarga dengan Status Gizi Balita Indonesia. Jurnal Ilmu Gizi FK UNAND. (Online), (http://repository.ipb.ac.id/bitstream/ handle/123456789/50164/ G08ish2).

Kementrian Kesehatan RI. 2014. Pedoman Gizi Seimbang (Pedoman Teknis bagi Petugas Dalam Memberikan Penyuluhan Gizi Seimbang). Jakarta: Kementrian Kesehatan RI 2014.

Kurniasih, N. \& Rosahdi, T.D. 2013. Perbandingan Efektivitas Sari $\mathrm{Ka}$ cang Merah dan Kacang Hijau sebagai Media Pertumbuhan Lactobacillus acidophilus, (Online), (digilib.batan.go.id/ppin/katalog/file/ 1858-3601-2013-_212- 216.pdf). Bandung: ptnbr-batan

Kusharto, C.M., Surono, I.S., \& Adi, A,C. 2009. Efikasi Pemberian Makanan Tambahan (PMT) Biskuit Fungsional Berbasis Sinbiotik dengan Prebiotik Asal Pangan Lokal dan Probiotik pada Balita Gizi Kurang. Bogor: Lembaga Penelitian dan Pengabdian Kepada Masyarakat Institut Pertanian Bogor.

Rosida. 2011. Pengaruh Pengolahan terhadap Daya Cerna Pati (secara invitro) pada Pisang. Jurnal Teknologi Pangan. (Online). (ejournal. Upnjatim.ac.id/index.php/rekapangan/ article/view/424). Surabaya: UPN Veteran.

Rukmi, A.S.I. 2009. Kadar Serat, Kadar Kalsium, Tekstur, dan Organoleptik Produk Ekstrusi Jagung dengan Substitusi Kacang Merah, (Online), (eprints.undip.ac.id/24789/). Bandung: Program studi Ilmu Gizi Fakultas Kedokteran UNDIP.

Setiawan, B. \&Yustiyani. 2013. Formulasi Bubur Instan Menggunakan Komposit Tepung Kacang Merah dan Pati Ganyong Sebagai Makanan 
Sapihan, Jurnal Gizi dan Pangan, 8(2): 95-102. (Online), (journal. ipb.ac.id).. Bogor: $\quad$ Fakultas Ekologi Manusia IPB.

Supriyadi, D. 2012. Pengaruh Rasio Amilosa-Amilopektin dan Kadar Air terhadap Kerenyahan dan Kekerasan Model Produk Gorengan. (Online). (repository.ipb.ac.id/handle/ 123456789/56987). Skripsi. Bogor: Teknologi Pangan Fakultas Teknologi Pertanian IPB.

Verawati. 2015. Pengaruh Substitusi Tepung Kacang Merah Terhadap Kualitas Kulit Pie. Skripsi. Padang: FT Universitas Negeri Padang.
Winarno, F. 2004. Kimia Pangan dan Gizi. Jakarta: PT. Gramedia Putaka Utama.

Yuliana, B.R. 2006. Aplikasi Tepung Kacang Merah sebagai Pengganti Tepung Terigu dan Pengaruhnya terhadap Karakteristik Sensoris, Fisik, dan Kimia pada Biskuit. (Online). (repository.unika.ac.id/ 7056). Skripsi. Semarang: Program Studi Teknologi Pangan Fakultas Teknologi Pertanian Universitas Katolik Soegijapranata. 